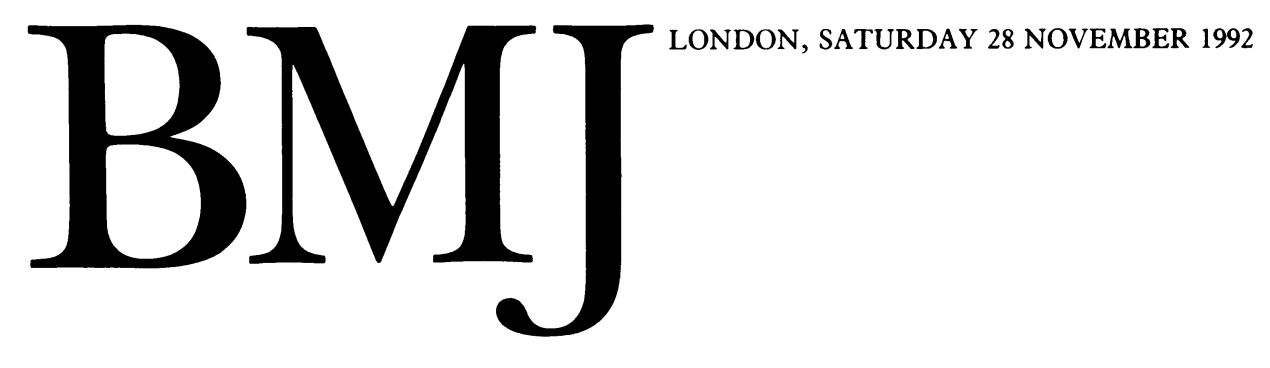

\title{
Letting vegetative patients die
}

\author{
Ethical and lawful and brings Britain into line
}

The doctor's dilemma so publicly discussed in the case of Tony Bland ( $p 1312)^{1}$ is the latest example of the need for medicine, ethics, and the law to adapt in the face of new situations created by emerging technologies. Those that can save or sustain the lives of patients who would previously have died enable many to make good recoveries, but a price is paid by patients who die after a fruitless fight in intensive care or survive with irreparable brain damage. Such treatment is justified only if there is a reasonable probability of meaningful recovery and of regaining life as a social person or if, in the words of the BMA's medical ethics committee, "it makes possible a decent life in which a patient can reasonably be thought to have a continued interest."'

Competent people considering consent to treatment that may leave them brain damaged are concerned about the quality of life and recognise that decisions depend on probabilities rather than certainties. ${ }^{3}$ Not only do competent patients have a right to refuse treatment (either at the time or by an advance directive) but doctors are also increasingly urged to avoid treatment when it is evident, either initially or after a trial of treatment, that a patient will not benefit. Indeed, doctors often decide not to resuscitate, not to embark on emergency surgery, or not to initiate or continue intensive care..$^{4-6}$ The decision to stop feeding vegetative patients is an extension of this good practice, although the trial of treatment must last months rather than days before futility can be declared.

These matters have been extensively debated in the public domain in the United States, where concern to protect the right of self determination has led to legislation. Natural death acts absolve doctors from liability for death after treatment has been limited at the patient's request; the 1991 Self Determination Act requires all patients to be informed on admission to hospital of their right to refuse treatment and to make an advance directive. Many cases have come to court in the United States for a decision to stop life sustaining treatment. At first most were about withdrawing ventilators, but these were soon overtaken by requests to stop tube feeding. There have been some 90 requests to stop tube feeding, mostly for vegetative patients, including one in the United States Supreme Court.

Last week's judgment therefore does no more than bring England into line with practice in the United States, Canada, New Zealand, and South Africa - where high court decisions have gone the same way. The Bland case has allowed public debate of issues already extensively explored in medical journals on both sides of the Atlantic, most recently in Britain by the Institute of Medical Ethics ${ }^{8}$ and the BMA. ${ }^{9}$ The outcome is not to recommend withdrawal of treatment from all vegetative patients but to confirm that it is a legitimate and ethically acceptable option that the families and doctors of some patients may consider. That further cases in England are to come to court will enable good practice to be established in a public forum. At a later stage guidelines might emerge and decisions might be made at a less formal level-for example, by ethics committees that have a broader remit than vetting research proposals.

The argument that food and water are basic needs that should never be denied rests on their normally assuaging the ravages of hunger and thirst and enabling a life that is enjoyed to continue. Neither applies to vegetative patients, and the symbolic significance of feeding is therefore lost. ${ }^{8}$ The BMA quotes a Roman Catholic moralist "that to persist with tube feeding can convey stupidity and cruelty, not compassion and love." As for the supposed unpleasant effects of discontinuing food and water, many reports from those with experience testify that with good nursing care death comes quietly and without changes that disturb the carers. ${ }^{10}$

The claim that respect for the sanctity of life requires doctors always to prolong life regardless of quality is rejected by both Catholic ${ }^{11}$ and Protestant ${ }^{12}$ authorities. Archbishop Coggan (of Canterbury) has written that it is "misleading to extend the term euthanasia to cover decisions not to preserve life by artificial means when it would be better for the patient to be allowed to die." 12

As to when it is safe to assume that the vegetative state is permanent rather than persistent, the BMA's suggestion of one year is consonant with all the evidence. ${ }^{29} \mathrm{~A}$ recent discussion of medical futility noted "the mythological power of the coma patient who wakes up to override the rarity of documented confirmation of such miraculous recoveries (which result moreover in incapacitating mental impairment and total dependency)." 13 The recovery of a limited degree of awareness may indeed be worse than non-sentience for the patient, whatever satisfaction it may bring to the carers. That was certainly the view of a Cambridge physicist in an appeal to doctors not to prolong life when it has lost most of its value. ${ }^{14}$ In the Lancet he wrote: "It adds fresh terror to traffic to know that an accident may make you an unconscious hulk lasting for years, a sorrow to any who love you and a trouble to all concerned, wasting valuable nurses and resources which should be used where they can do good. At best, you could die 
in the end unconscious, at worst, recover some degree of awareness and live indefinitely, deprived of those powers that distinguish us from the lower animals. The ability to prolong life may be a curse instead of a blessing." He, like many others, will be reassured by the judgment in the Bland case.

BRYAN JENNETT

Emeritus Professor,

Department of Neurosurgery,

Institute of Neurological Sciences,

Glasgow G51 4TF

1 Dyer C. High Court rules doctors can stop feeding Tony Bland. BMf 1992;305:1312.

2 BMA Medical Ethics Committee. Discussion paper on treatment of patients in persistent vegetative state. London: BMA, 1992.
3 Jennett B, Boyd KM. Managing the persistent vegetative state. BMF 1992;305:886-7.

4 Ruark JE, Raffin TA, Stanford Medical Center Committee on Ethics. Initiating and withdrawing life support: principles and practice in adult medicine. $N$ Engl f Med 1988;318:25-30.

5 Barlow P, Jennett B. Decisions to limit treatment in a neurosurgical unit: an aspect of audit of mortality. Scott Med F 1991;36:109-11.

6 Smedira NG, Evans BH, Grais LS, Cohen NK, Lo B, Cooke M, et al. Withholding and withdrawal of life support from the critically ill. $N$ Engl $\mathcal{F}$ Med 1990;3:309-14.

7 Jennett B, Dyer C. Persistent vegetative state and the right to die: the United States and Britain BMf 1991;302:1256-8.

8 Institute of Medical Ethics. Working party report on withdrawing life supporting treatment from patients in a vegetative state after acute brain damage. Lancet 1991;337:96-8.

9 Dyer C. BMA examines the persistent vegetative state. BMF 1992;305:853-4.

10 Ahronheim JC, Grasner MR. The sloganism of starvation. Lancet 1990;335:278-9.

11 Paris JJ, McCormick RA. The Catholic tradition on the use of nutrition and fluids. America 1987 May 2:356-61.

12 Coggan D. On dying and dying well: spiritual and moral aspects. Proc $R$ Soc Med 1977;70:75-81.

13 Schneiderman LJ, Jecker NS, Jonsen AR. Medical futility: its meaning and ethical implication Ann Intern Med 1990;112:949-54.

14 Thomson GP. An appeal to doctors. Lancet 1969;ii: 1353.

\section{The architecture of cancer}

\section{The tissue metalloproteinases and their inhibitors}

Tumours may spread by releasing degradative enzymes called metalloproteinases that disrupt the normal surrounding extracellular architecture. In health this extracellular matrix is regulated by a complex interplay of enzymes and inhibitory proteins that include the metalloproteinases and their tissue inhibitors. Malignancy and the arthritides disrupt this physiological cascade. ${ }^{1}$

First described in 1962 by Gross and LaPierre in the tail of the metamorphosing tadpole, metalloproteinases control normal processes such as morphogenesis and angiogenesis and have a central role in uterine involution and cervical softening. A group of multidomain, zinc binding, calcium dependent enzymes, the metalloproteinases are secreted as proenzymes and activated by cleavage of a propeptide. Their most recent classification describes two collagenases, two gelatinases, three stromelysins, and matrilysin. ${ }^{2}$

There is cross species conservation of the enzymes' structure and considerable sequence homology between the metalloproteinase genes..$^{3-5}$ The metalloproteinases are regulated at a post-translational level by $\alpha_{2}$ macroglobulin and plasmin, together with specific tissue inhibitors of metalloproteinases type 1-4, of which two have been sequenced.$^{67}$ Post-transcriptional regulation is by interleukins alpha and beta, transforming growth factor beta, tumour necrosis factor alpha, and fibroblast growth factor. Metalloproteinase genes and oncogenes interact, ${ }^{89}$ although how they do so has not been precisely delineated.

The metalloproteinases and their inhibitors are components of paracrine loops implicated in tissue invasion and metastasis. In local invasion the metalloproteinases' role may be to promote the escape of malignant cells from the primary tumour; in metastasis, metalloproteinases may assist distant seeding. Increase in tissue concentrations of metalloproteinase messenger RNA or immunoreactivity has been described in endometrial, ovarian, gastric, colonic, prostatic, breast, non-small cell lung, and head and neck cancers and in melanoma and leukaemia. In these tumour groups increased concentrations of metalloproteinase correlated with invasiveness and metastatic state and exceeded those found in benign tumours and normal adjacent tissue. ${ }^{10-19}$

Tumours may also produce metalloproteinase inhibitors. ${ }^{20}$ In a comparison of non-metastatic and metastatic murine mammary adenocarcinoma cell lines, lower concentrations of metalloproteinase inhibitors were found in the metastatic cells, suggesting a possible role for inhibitors in metastasis. ${ }^{21}$

Recently monoclonal antibodies have been developed that can detect metalloproteinases and their inhibitors in human serum. Higher concentrations of interstitial collagenase and tissue inhibitors of metalloproteinases- 1 have been found in $ᄋ$ patients with metastatic prostatic cancer than in controls matched for age and patients with localised prostatic cancer. ${ }^{\infty}$ Concentrations of metalloproteinases predicted response to treatment ( $\mathrm{T}$ Baker et al, British Association for Cancer $\$$ Research winter meeting 1992). Metalloproteinases therefore $\underset{\mathbb{Q}}{\overrightarrow{0}}$ seem to be produced by tumours; whether metalloproteinase inhibitors are produced by the tumour or its host-as a $\vec{\bullet}$ defence against tumour invasion - is not established. Studies ? using in situ hybridisation favour the defence hypothesis.

These early observations have led to tentative hopes of therapeutic benefit from manipulating the metalloproteinases and metalloproteinase inhibitors. These hopes have grown $\frac{\mathscr{O}}{\mathbb{Q}}$ along several theoretical strands whose roots include peptide $\stackrel{\square}{\Rightarrow}$ inhibitors of the metalloproteinases, antisense treatment, and $\bar{\circ}$ gene transfection. A single peptide sequence, which is $\frac{3}{5}$ involved in coordinating the catalytic zinc atom of the active site, is present in all known members of the metalloproteinase family. In vitro studies have shown that a synthetic peptide incorporating a modification of this sequence inhibits tumour invasion $^{22}$; this could be used therapeutically. Down modula- 3 . tion of tissue inhibitors of metalloproteinases by antisense $\delta$ RNA converts non-tumorgenic Swiss 3T3 fibroblast lines $₹$ into malignant cells forming metastatic tumours. Increased음 secretion of metalloproteinases accompanies this. ${ }^{23}$ Down regulation of protease activity has been achieved in rat $\rightarrow$ tumours by transfection with the cDNA of tissue inhibitors of metalloproteinases-2. These cells secreted inhibitor protein, $N$ and their ability to form lung metastases was reduced. ${ }^{24} \mathrm{~N}$ Deciding which approach has more therapeutic potential is impossible without further investigation.

Most deaths from malignancy occur as a result of metastatic $\stackrel{\frac{0}{\Phi}}{\bar{C}}$ disease despite the apparent cure of the primary tumour. This ${ }^{\mathcal{P}}$ progression to metastatic cancer could be limited by metallo- $T$ proteinase inhibition. Futuristic technologies using inhibi- $\frac{O}{\mathbb{D}}$

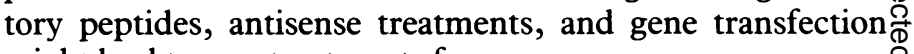
might lead to new treatments for cancer.

JONATHAN WAXMANo̊ Reader in Oncology

HARPREET WASAN

Department of Clinical Oncology, Senior Registrar $\stackrel{?}{?}$

London W12 0NN 